ISSN : 2252-3839 (Print)

ISSN : 2549-2403 (On Line)

DOI : 10.28989/compiler.v9i1.633

http://ejournals.stta.ac.id/index.php/compiler/

\title{
COMPARISON OF QUICKSORT AND MERGESORT METHOD FOR USER INTERFACE AND USER EXPERIENCE ASSESSMENT IN ADISUTJIPTO COLLEGE OF TECHNOLOGY
}

\author{
Muhammad Zainal Abidin ${ }^{1}$, Dwi Nugraheny ${ }^{2}$, Yuliani Indrianingsih ${ }^{3}$ \\ Program Studi Teknik Informatika \\ Sekolah Tinggi Teknologi Adisutjipto \\ Jl. Janti Blok-R Lanud Adisutjipto Yogyakarta \\ Email : ${ }^{1}$ zen.zaieen@gmail.com, ${ }^{2}$ henynug@gmail.com, ${ }^{3}$ yulistta@gmail.com
}

\begin{abstract}
This study is intended to assess the user interface and user experience on the Adisutjipto College of Technology website using the mergesort method and compared with the quicksort method in finding the highest value of several variables or elements that are categorized as good or good in order to improve the quality of the Adisutjipto College of Technology website. The results of the study show that the quicksort method is faster in the process of calculating questionnaire data than the merge method with an average time record of 0.476667 seconds for the quicksort method and 0.576667 seconds for the mergesort method. The results of the comparison of the two methods on the questionnaire website to assess the accuracy in terms of user interface and user experience on the Adisutjipto College of Technology website, that the mergesort method is more accurate than the quicksort method, the Usability category scores the highest, while the Expressive aesthentics category has the lowest value.
\end{abstract}

Kata Kunci: Kuisioner, Mergesort, User Interface, User Experience, Quicksort.

\section{Latar Belakang Masalah}

Bagi pencari informasi, akurasi, relevansi, dan atau kelengkapan akan membuat situs web lebih berguna serta dapat mengakses informasi yang dibutuhkan secara lebih tepat dan lebih bermanfaat. Jadi karakteristik penting dari situs web adalah kemampuannya untuk menyediakan komunikasi yang disesuaikan untuk memenuhi kebutuhan unik konsumen [1],[2]. Menurut [3], user interface penting pada sistem aplikasi karena hampir semua aplikasi memiliki antarmuka pengguna, Interface yang buruk membuat frustasi bagi pengguna dan akan mempengaruhi produktivitas. User interface merupakan unsur yang paling penting dari sebuah sistem berbasis komputer atau produk [4]. User experience mempunyai pandangan yang lebih luas, yakni melihat seluruh interaksi individu dengan objek, serta pikiran, perasaan, dan persepsi yang dihasilkan dari interaksi tersebut, [5].

Pada penelitian [6], tentang Penerapan Metoda Pengurutan Quicksort untuk menganalisa User Interface dan User Experience Website Sekolah Tinggi Teknologi Adisutjipto (STTA) Yogyakarta dibandingkan pengolahan dengan statistik cronbach (Aplikasi Statistik). Diperoleh hasil, bahwa Website STTA memiliki Usability dan Quality of Information (kualitas informasi) yang "baik", serta memiliki Content, Pleasure, Classic Aesthetics, Expressive Aesthetics yang "cukup" Terkait dengan penjelasan tersebut, tentang Analisis User Interface dan User Experience pada Website STTA Yogyakarta diperoleh hasil bahwa Website STTA memiliki Usability dan Quality of Information (kualitas informasi) 
yang "baik", serta memiliki Content, Pleasure, Classic Aesthetics, Expressive Aesthetics yang "cukup".

Berdasarkan uraian di atas, pada penelitian ini menjelaskan tentang perbandingan dengan 2 (dua) metode yaitu quicksort dan mergesort untuk mengolah data-data kuisioner dari para pengguna website Sekolah Tinggi Teknologi Adisutjipto (STTA) dalam menentukan metode mana yang cepat pengolahan datanya dan mengolah data secara akurat dari sudut pandang user interface,[2], [3] dan user experience [5] dari beberapa variabel kategori yaitu usability, content, pleasure, classic aesthetics, expressive aesthetics serta quality of Information (kualitas informasi).

\section{Metodologi Penelitian.}

Penelitian ini menggunakan 2 (dua) metode yaitu metode quicksort [12].[13] dan mergesort [12],[13] untuk mengolah data-data dalam menentukan metode mana yang paling sesuai dan paling akurat pada website di STTA Yogyakarta dengan beberapa variabelvariabel atau unsur-unsur dari sudut pandang user interface dan user experience yang merupakan bagian dari Human Computer Interaction (HCI). Adapun variabel-variabel atau unsur-unsur dari sudut pandang user interface dan user experience yaitu usability, content, pleasure, classic aesthetics, expressive aesthetics serta quality of Information. Menurut [7], Usability melingkupi aplikasi yang mudah dipelajari (learnbility), memiliki keluwesan (flexibility), serta memiliki kehandalan (robustness). Content adalah informasi yang tersedia melalui media atau produk elektronik [8], Pleasure, dimaksudkan sistem yang disajikan menarik sehingga pengguna merasa senang menggunakan sistem tersebut berkaitan dengan unsur usability [7],[9]. Menurut [10] Classic Aesthetics merujuk gagasan tradisional yang menekankan pada desain yang tertib dan jelas terhadap tampilan berkaitan dengan bidang ilmu Human Computer Interaction (HCI). Expressive Aesthetics menurut [10], lebih tertuju pada kreativitas desain dan orisinalitas. Menurut [11] Expressive Aesthetics lebih mencerminkan desain pada kreativitas, imajinasi, dan orisinalitas kekayaan desain, dan desain yang lebih kompleks. Quality of Information (kualitas Informasi), menurut [12] bahwa kualitas dari suatu informasi tergantung dari 3 (tiga) hal yaitu informasi harus akurat (accurate), tepat waktu (timelines) dan relevan (relevance)

Beberapa langkah yang digunakan dalam penyelesaian penelitian ini dijelaskan pada gambar 1. Pada langkah tersebut dijelaskan bahwa pengolahan hasil aplikasi kuisioner web menggunakan dua metode quicksort dan mergesort. Hasil pengolahan kuisioner web berdasarkan 6 (enam) variabel atau unsur yaitu usability, content, pleasure, classic aesthetics, expressive aesthetics, serta quality of Information dikelompokkan dalam bentuk beberapa pertanyaan. Kemudian beberapa pertanyaan yang sudah terkelompokkan tersebut dianalisa untuk mengetahui metode mana menghasilkan hasil yang paling baik dari ke enam variabel tadi di website STTA Yogyakarta 


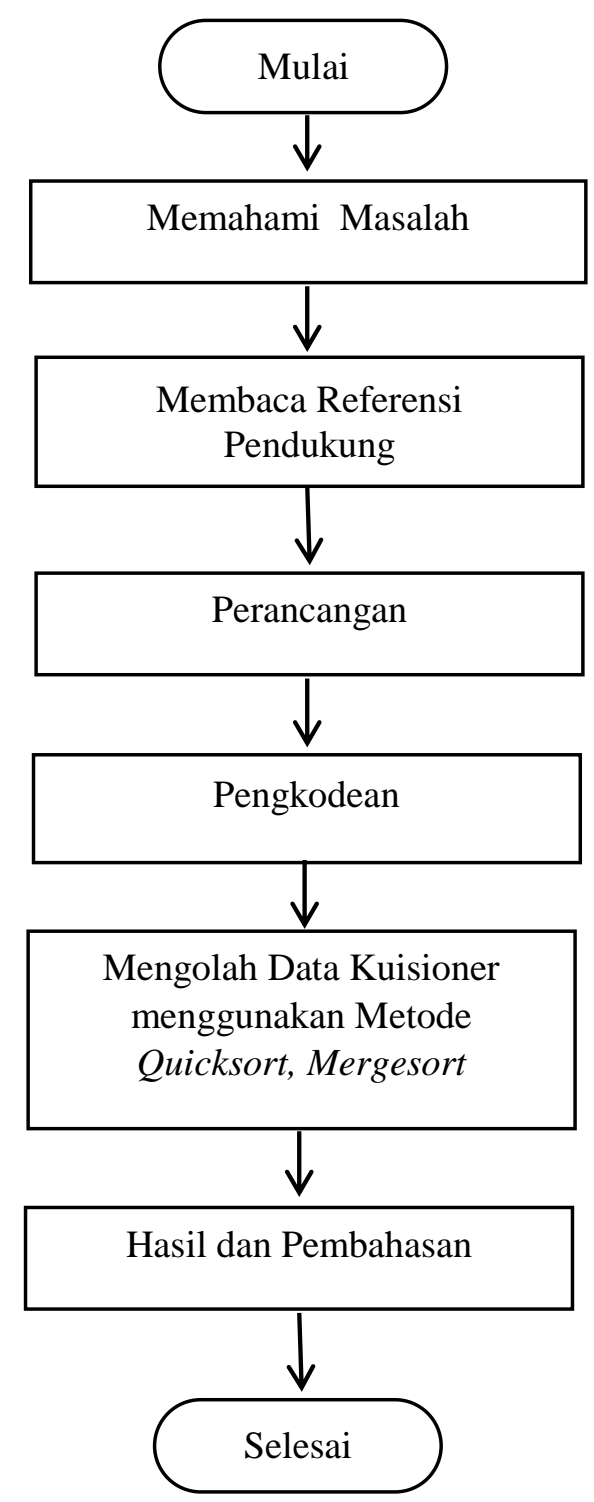

Gambar 1. Langkah-langkah dalam proses penelitian

\subsection{Perancangan Use Case Diagram}

Use case diagram adalah model fungsional dari sebuah sistem yang mempresentasikan sebuah interaksi antara actor dengan sistem itu sendiri. Actor merupakan entitas yang umumnya digambarkan sebagai manusia atau mesin yang berinteraksi dengan sistem untuk melakukan pekerjaan-pekerjaan tertentu [14]. Gambar 2 menjelaskan use case diagram untuk aplikasi kuisioner dalam membandingkan data-data variabel user interface dan user experience menggunakan metode quicksort dan mergesort. Aplikasi ini melibatkan 2 (dua) actor yaitu user dan admin. User dalam hal ini adalah para pengguna website Sekolah Tinggi Teknologi Adisutjipto (STTA) yang dominan adalah para mahasiswa dan mahasiswi STTA. Sedangkan admin adalah pengelola web yang berada pada unit Teknologi Informasi dan Komputer (TIK). 


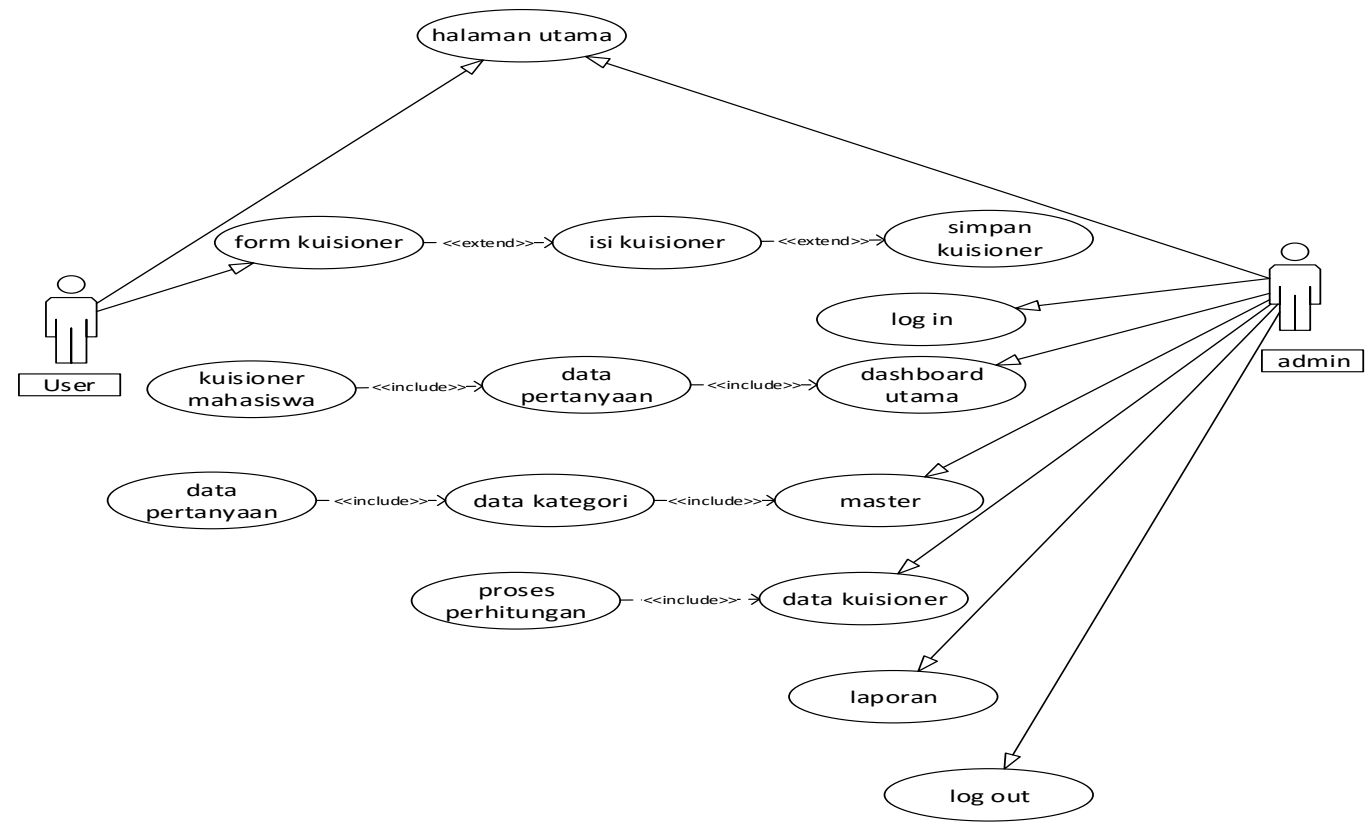

Gambar 2. Use case diagram aplikasi kuisioner pada web STTA

\subsection{Perancangan Class Diagram}

Class diagram merupakan class yang spesifik untuk menghasilkan objek agar menjadi inti dari pengembangan sistem yang berorientasi objek. Class diagram juga menggambarkan sturktur dan deskripsi class, package dan objek beserta hubungan satu sama lain seperti containment, pewarisan, asosiasi, dan lain-lain, [14]. Gambar 3 menjelaskan class diagram pada aplikasi kuisioner web STTA yang akan diolah menggunakan metode quicksort dan mergesort.

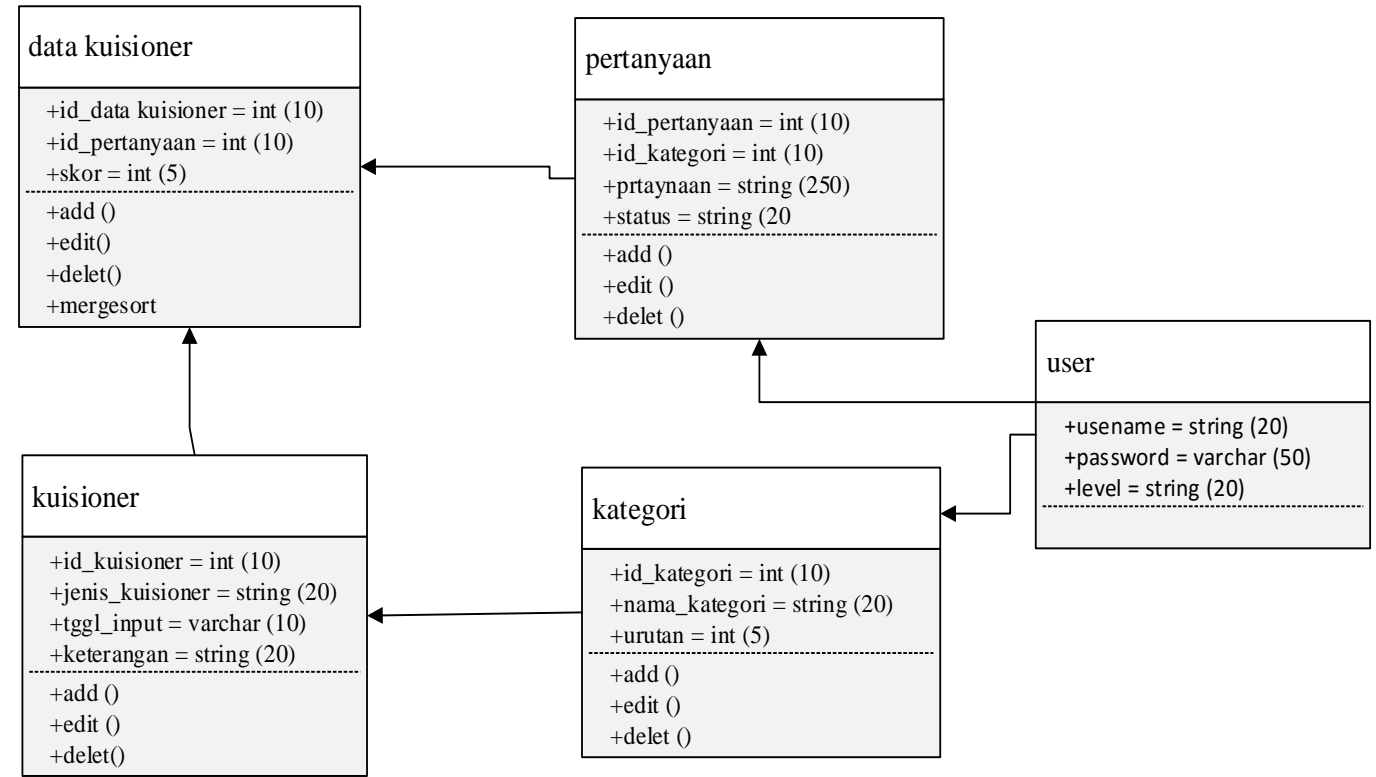

Gambar 3. Class diagram aplikasi kuisioner pada web STTA

\subsection{Perancangan Perancangan Form Menu Data Kategori}

Perancangan form menu data kuisioner ini akan menampilkan data kategori pertanyaan (Gambar 4), dimana di dalam form menu data kategori terdapat keterangan Id 
kategori, Nama kategori, dan Urutan kategori. Pertanyaan-pertanyaan yang dibuat dikelompokkan sesuai pada Urutan kategori pertanyaan.

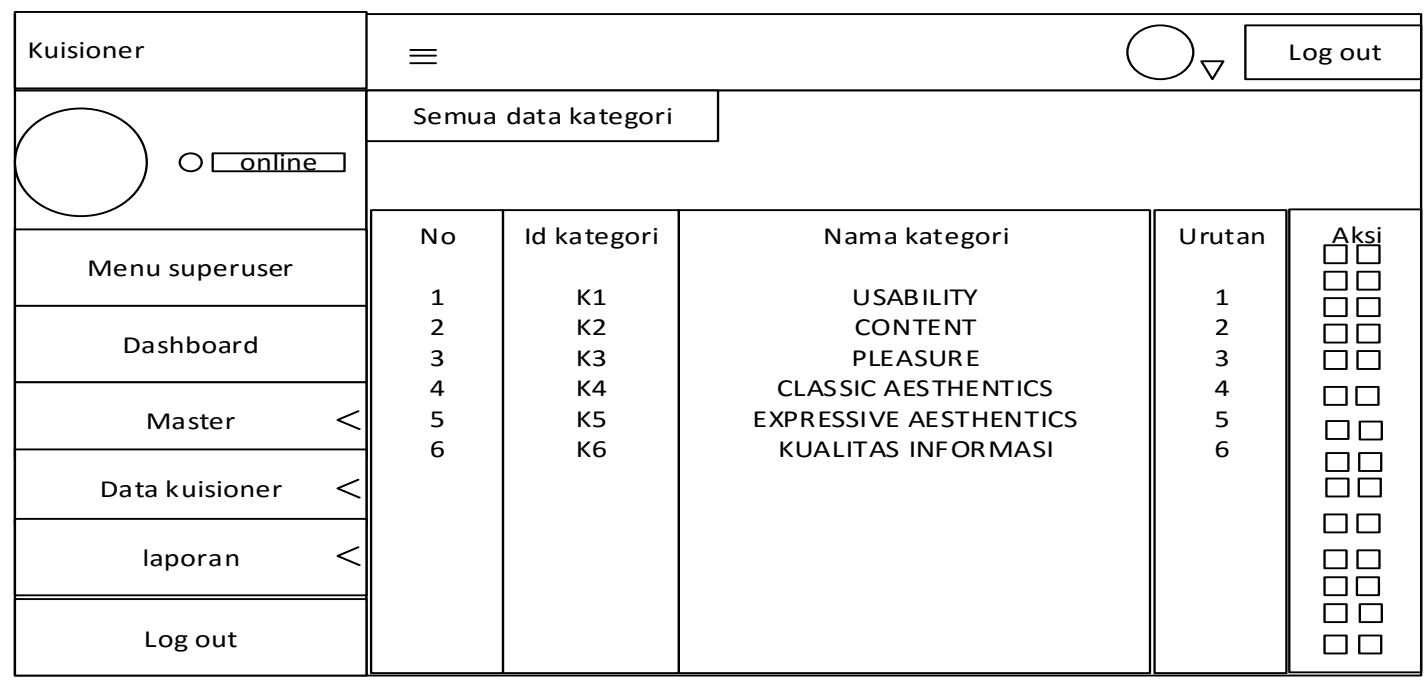

Gambar 4. Perancangan form menu data kategori.

\subsection{Perancangan Form Menu Laporan Hasil Kuisioner}

Perancangan form menu laporan hasil kuisioner ini akan menampilkan hasil dari proses perhitungan menggunakan metode mergesort, laporan yang ditampilkan tersebut sudah menyeluruh atau menjadi hasil akhir dari proses kuisioner.web, kemudian laporan ini dapat langsung dicetak atau di-print.

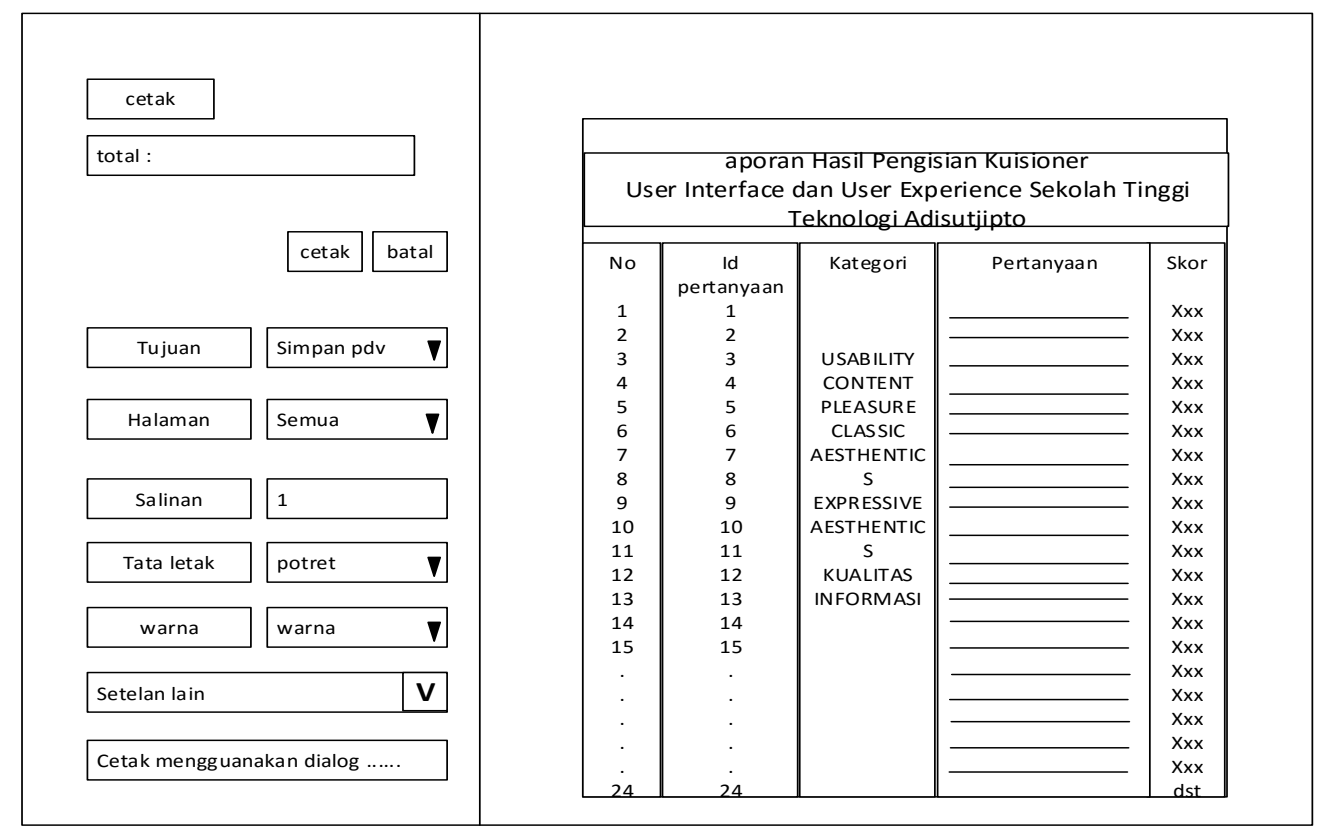

Gambar 5. Perancangan form menu laporan hasil kuisioner

\section{Hasil dan Pembahasan}

Gambar 6 merupakan halaman form menu data kategori yang berisi urutan dan kelompok kategori (usability, content, pleasure, classic aesthetics, expressive aesthetics serta quality of Information) dalam bentuk beberapa pertanyaan yang disediakan di dalam kuisioner web. Pertanyaan-pertanyaan tersebut dibagi menjadi beberapa kelompok kategori. 


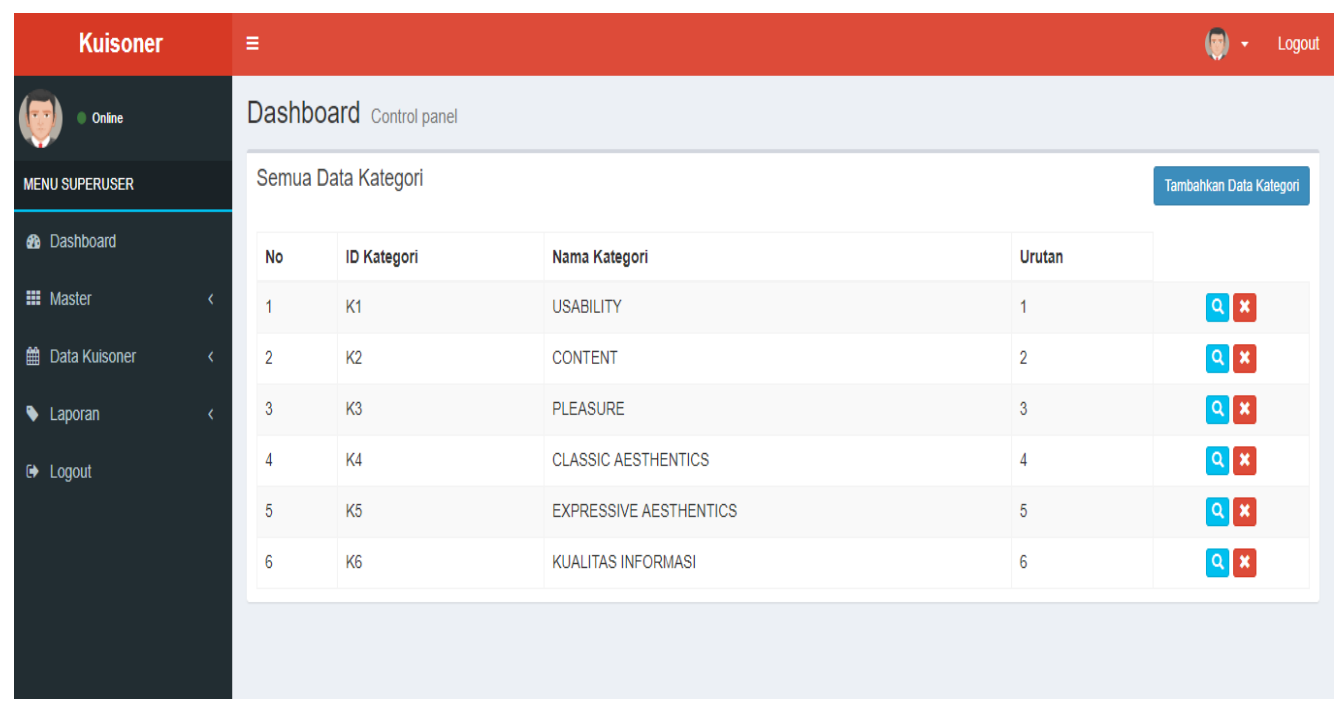

Gambar 6. Halaman Form Menu Data Kategori

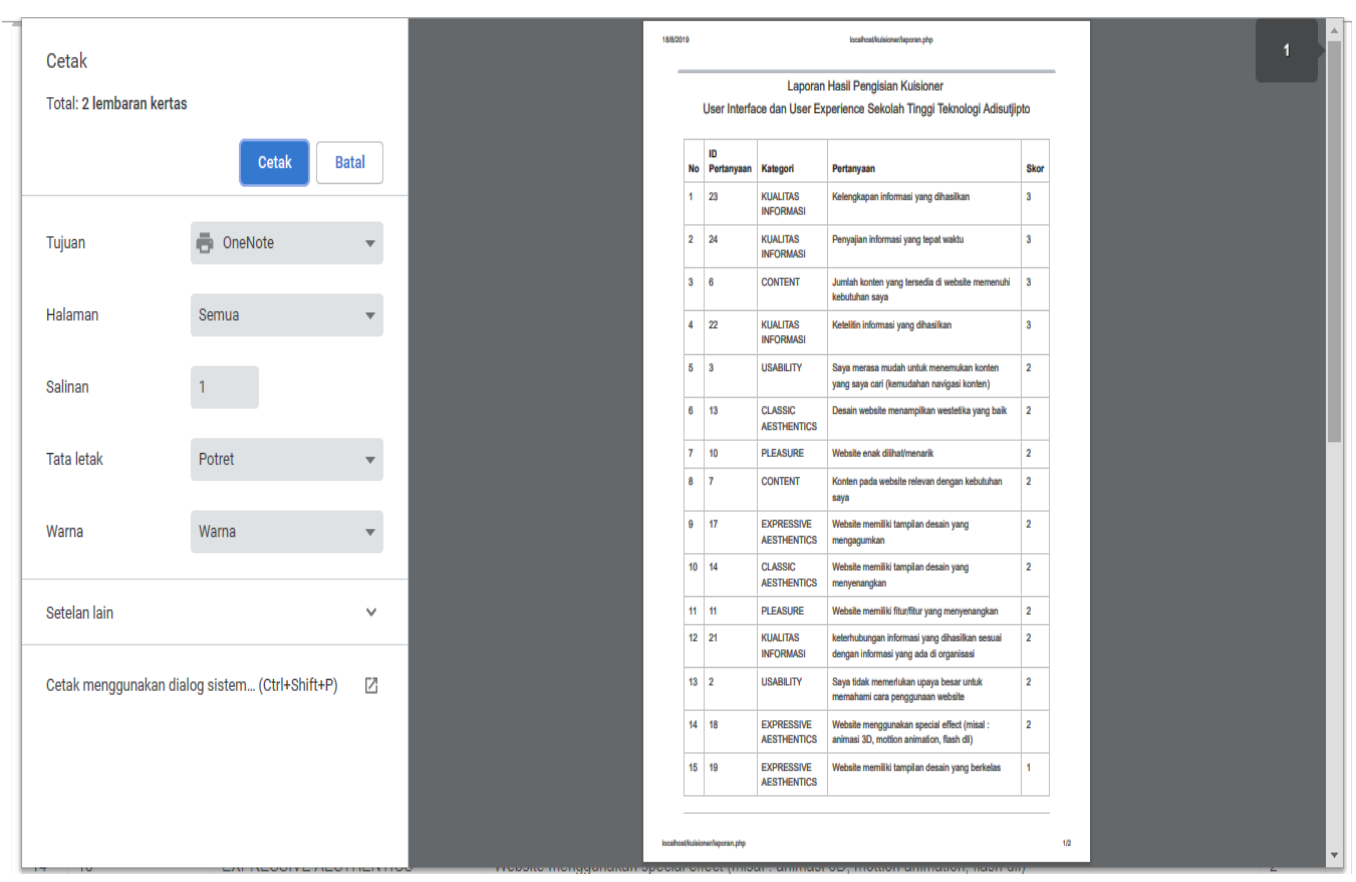

Gambar 7. Tampilan Halaman Form Menu Hasil Laporan Kuisioner.

Gambar 7 merupakan halaman form menu laporan hasil kuisioner, yang berisi informasi semua data hasil kuisioner yang sudah diproses dan terhitung serta telah diurutkan. Hasil pertanyaan dari 6 (enam) kategori variabel dilakukan perhitungan dalam bentuk skor. Kemudian dilakukan penentuan pivot yang digunakan sebagai poros untuk melakukan perbandingan nilai-nilai skor pada bagian kiri dan bagian kanan pivot. Jika pada nilai skor < pivot, maka nilai skor ditukar ke bagian kiri pivot. Jika pada nilai skor > pivot, maka nilai skor ditukar ke bagian kanan pivot. Tabel 1 merupakan hasil perhitungan untuk perbandingan kecepatan pengolahan data-data kuisioner menggunakan metode mergesort dan quicksort. 
Table 1. Perbandingan Kecepatan Perhitungan Kuisioner dengan Metode Mergesort dan Quicksort

\begin{tabular}{|c|c|c|}
\hline Pengujian & Mergesort (detik) & Quicksort (detik) \\
\hline Uji coba 1 & 0,60 & 0,48 \\
\hline Uji coba 2 & 0,61 & 0,47 \\
\hline Uji coba 3 & 0,52 & 0,48 \\
\hline
\end{tabular}

Adapun perhitungan rata-rata kuisioner pada tabel 1 menggunakan rumus:

Rata - rata $=\frac{\text { Jumlah Nilai }}{\text { Banyak data }}$

Sehingga rata-rata kecepatan perhitungan kuisioner dengan metode mergesort yaitu:

Rata - rata $=\frac{(0,60+0,61+0,52)}{3}$

$=0,576667$ detik

Sedangkan rata-rata kecepatan perhitungan kuisioner dengan metode quicksort yaitu ;

$$
\begin{aligned}
\text { Rata }- \text { rata }= & \frac{(0,48+0,47+0,48)}{3} \\
& =0,476667 \text { detik }
\end{aligned}
$$

Hasil rata-rata perhitungan kuisioner dalam hal kecepatan untuk proses sorting sejumlah 30 data kuisioner yang ada pada website Sekolah Tinggi Teknologi Adisutjipto (STTA), maka metode quicksort lebih unggul dari metode mergesort. Nilai 0,476667 detik untuk nilai metode quicksort dan 0,576667 detik untuk nilai metode mergesort.

Tabel 2 merupakan hasil nilai perbandingan proses keakuratan data yang dilakukan pada kuisioner website berdasarkan beberapa variabel user interface dan user experience dengan metode mergesort dan quicksort. .

Tabel 2. Hasil Nilai Perbandingan Keakuratan Data Kuisioner Website

\begin{tabular}{|c|l|l|l|}
\hline $\begin{array}{c}\text { Uji } \\
\text { coba }\end{array}$ & \multicolumn{1}{|c|}{ Kategori Variabel } & $\begin{array}{c}\text { Data nilai proses } \\
\text { perhitungan dengan } \\
\text { Mergesort }\end{array}$ & $\begin{array}{c}\text { Data nilai proses } \\
\text { perhitungan } \\
\text { dengan Quicksort }\end{array}$ \\
\hline Uji 1 & $\begin{array}{l}\text { Usability } \\
\text { Expressive aesthentics }\end{array}$ & $\begin{array}{l}\text { Data tertinggi }=115 \\
\text { Data terendah }=98\end{array}$ & $\begin{array}{l}\text { Data tertinggi }=116 \\
\text { Data terendah }=101\end{array}$ \\
\hline Uji 2 & $\begin{array}{l}\text { Usability } \\
\text { Expressive aesthentics }\end{array}$ & $\begin{array}{l}\text { Data tertinggi }=115 \\
\text { Data terendah }=98\end{array}$ & $\begin{array}{l}\text { Data tertinggi }=116 \\
\text { Data terendah }=101\end{array}$ \\
\hline Uji 3 & $\begin{array}{l}\text { Usability } \\
\text { Expressive aesthentics }\end{array}$ & $\begin{array}{l}\text { Data tertinggi }=115 \\
\text { Data terendah }=98\end{array}$ & $\begin{array}{l}\text { Data tertinggi }=116 \\
\text { Data terendah }=101\end{array}$ \\
\hline
\end{tabular}

Hasil proses perhitungan pada tabel 2, bahwa nilai data tertinggi untuk keakuratan pengurutan hasil pengolahan data kuisioner di website STTA menggunakan metode mergesort dan metode quicksort adalah kategori variabel usability yaitu bernilai 116 (dengan metode quicksort) dan nilai 115 (dengan metode mergesort), artinya bahwa website STTA mudah dipelajari (learnbility), memiliki keluwesan (flexibility), serta memiliki kehandalan (robustness) [7]. Sedangkan pengurutan hasil pengolahan data kuisioner di website STTA kategori variabel terendah adalah Expressive aesthentics yaitu bernilai 101 (dengan metode 
quicksort) dan nilai 98 (dengan metode mergesort), artinya bahwa website STTA untuk desain kreativitas, imajinasi, dan orisinalitas kekayaan desain, dan desain yang lebih kompleks perlu dilakukan evaluasi kembali sehingga selanjutnya akan berpengaruh pada penilaian aspek satisfaction dan pleasure pengguna dalam menggunakan website.

Jika dibandingkan pada penelitian sebelumnya oleh [6] menggunakan metode quicksort dan dengan metode uji statistik cronbach, diperoleh rata-rata hasil uji variabel usability yang tinggi, sedangkan variabel expressive aesthetics memiliki nilai yang rendah hal ini berindikasi pada user interface dan user experience. Sehingga pada penelitian [6] dan penelitian ini memiliki hasil yang sama untuk pengurutan variabel usability memiliki nilai tertinggi dan variabel expressive aesthentics memiliki nilai terendah.

\section{Kesimpulan}

Berdasarkan hasil pengujian perbandingan pada aplikasi kuisioner website di Sekolah Tinggi Teknologi Adisutjipto (STTA) dengan menggunakan metode mergesort dan quicksort ini dapat diambil beberapa kesimpulan yaitu:

1. Perbandingan kecepatan dalam pengurutan data dengan sejumlah 30 data kuisioner website, maka proses pengolahan data dengan metode quicksort lebih cepat yaitu dengan nilai waktu rata-rata 0,476667 detik dibanding dengan metode mergesort dengan nilai waktu rata-rata 0,576667 detik.

2. Keakuratan data yang dihasilkan dalam hal pengurutan data berdasarkan 6 (enam) variabel dari sudut pandang user interface dan user experience yaitu usability, content, pleasure, classic aesthetics, expressive aesthetics serta quality of Information, dengan metode quicksort maupun dengan metode mergesort yang memiliki nilai tertinggi adalah kategori usability-sedangkan kategori expressive aesthentics memiliki nilai terendah.

\section{Daftar Pustaka}

[1] Ghose, S., \& Dou, W. (1998). Interactive functions and their impacts on the appeal of Internet presence sites. Journal of Advertising research, 38(2), 29-43.

[2] Loiacono, E. T., Watson, R. T., \& Goodhue, D. L. (2002). WebQual: A measure of website quality. Marketing theory and applications, 13(3), 432-438.

[3] De Troyer, O., \& Casteleyn, S. (2004, November). Designing localized web sites. In International Conference on Web Information Systems Engineering (pp. 547-558). Springer, Berlin, Heidelberg.

[4] Sridevi, S. (2014). User interface design. International Journal of Computer Science and Information Technology Research, 2(2), 415-426.

[5] Albert, W., \& Tullis, T. (2013). Measuring the user experience: collecting, analyzing, and presenting usability metrics. Newnes.

[6] Heny, D. N. (2017, December). Penerapan Metoda Pengurutan Quicksort Untuk Menganalisa User Interface Dan User Experience Website Sekolah Tinggi Teknologi Adisutjipto Yogyakarta. In Conference SENATIK STT Adisutjipto Yogyakarta (Vol. 3, pp. 174-181).

[7] Dix, A., Dix, A. J., Finlay, J., Abowd, G. D., \& Beale, R. (2003). Human-computer interaction. Pearson Education.

[8] Prayogaperdana.com. 2014. 'Pengertian Website, Tentang Website, Apa itu Website' http://webdesign.about.com/od/content/qt/what-is-web-content.htm,

[9] Freud, S. (2003). Beyond the pleasure principle. Penguin UK. 
[10] Ahmed, S. U., Al Mahmud, A., \& Bergaust, K. (2009, July). Aesthetics in humancomputer interaction: Views and reviews. In International Conference on HumanComputer Interaction (pp. 559-568). Springer, Berlin, Heidelberg.

[11] Lavie, T., \& Tractinsky, N. (2004). Assessing dimensions of perceived visual aesthetics of web sites. International journal of human-computer studies, 60(3), 269298.

[12] Sutabri, T. (2004). Analisa Sistem Informasi, Edisi 1. Penerbit Andi: Yogyakarta.

[13] Santosa, P. I. (2001). Struktur Data Menggunakan Turbo Pascal 6.0. Andi Yogyakarta.

[14] Sismoro, H., \& Iskandar, K. (2004). Struktur Data dan Pemrograman dengan pascal. Andi Yogyakarta, Yogyakarta.

[15] Eriksson, H.E, dkk. 2004. UML 2 Toolkit. Wiley Publishing Inc. Indianapolis, Indiana.http://www.ecotec.edu.ec/documentacion\%5Cinvestigaciones\%5Cdocentes_y _directivos\%5Carticulos/6008_TRECALDE_00278.pdf. Diakses pada tanggal 25 Agustus 2019.

[16] Fowler, M. (2004). UML distilled: a brief guide to the standard object modeling language. Addison-Wesley Professional. 
Muhammad Zainal Abidin, Dwi Nugraheny, Yuliani Indrianingsih 